\title{
Relationship between forest biodiversity attributes and potential carbon stocks in dry tropical reserve forests of Assam, northeast India
}

\author{
Gisandu K. Malunguja ${ }^{1,2 *}$, Bijay Thakur', Ashalata Devi ${ }^{1}$ \\ ${ }^{1}$ Department of Environmental Science, School of Sciences, Tezpur University, PIN-784028, Tezpur, \\ Assam, India \\ ${ }^{2}$ Department of Technical Education, College of Sciences, Mbeya University of Science and \\ Technology, Box 131, Mbeya, Tanzania \\ ${ }^{\star}$ Corresponding author, E-mail: gmalunguja77@gmail.com
}

\begin{abstract}
Potential forest carbon stocks are significantly correlated to forest biodiversity attributes such as diversity, density, and richness. However, there is little such information on dry tropical reserve forests of Assam, a state in northeast India. We studied this relationship in two reserve forests. Pearson correlation, cluster analysis, and regression analysis were used to explore these relationships. The estimation of plant carbon stocks was made using both destructive methods for herbaceous and non-destructive allometric methods for trees. The most dominant plant species in the Bhomoraguri reserve forest were Cynodon dactylon, Datura stramonium, Clitoria ternatea, and Tectona grandis for grasses, forbs, climbers, and trees, respectively. Cymbopogon nardus, Colocasia esculenta, Mikania micrantha, and Shorea robusta, were dominant species in the Balipara reserve forest for grasses, forbs, climbers, and trees, respectively. The presence of Lantana camara, Smilax ovalifolia and Piper betle in the studied forests suggests disturbed ecosystems. Other observed species such as Aristida spp., Cenchrus spp., Ipomoea cheirophylla, and Sida spp. are indicators of disturbed ecosystems as well. The biomass stock differed significantly among plant growth forms. Carbon stocks were 302.93 and $283.97 \mathrm{t} \mathrm{ha}^{-1}$ in the Bhomoraguri reserve forest and Balipara reserve forest, which were equivalent with 555.87 and $521.30 \mathrm{t} \mathrm{ha}^{-1} \mathrm{of} \mathrm{CO}_{2}$ sequestration, respectively. Tree species contributed the greatest amount (54.80\%), followed by forbs (21.36\%), climbers (19.35\%), and least for grasses (4.49\%). Correlation analysis indicated a strong positive relationship between the density of trees and climber species with carbon stock potentials, suggesting that increase of their density favoured carbon sequestration in forest ecosystems. Diversity of grasses was negatively correlated with potential carbon stock in the examined forests. The unique contribution of each group to carbon stock was 91.8, 58.01, 51.3, and 11.11\% for climbers, trees, grasses, and forbs, respectively. Thus, it is important to examine biodiversity attributes in estimation of forest carbon stocks.
\end{abstract}

Key words: biomass production; carbon sequestration; herbaceous layer; plant diversity; reserve forests.

Abbreviations: AGB, aboveground biomass; BGB, belowground biomass; C, carbon stocks; $\mathrm{CO}_{2} \mathrm{e}$, carbon dioxide equivalent; dbh, diameter at breast height; DM, dry matter content; TB, total biomass; TC, total carbon.

\section{Introduction}

Tropical forests are global biodiversity hotspots that play an important role in species conservation and provide various other vital ecosystem services (Dibaba et al. 2019; Pradhan et al. 2019; Kothandaraman et al. 2020; Raha et al. 2020). Studies have reported a significant positive correlation between carbon stocks in forest ecosystems and plant diversity and structural attributes (Banik et al. 2018; Kothandaraman et al. 2020; Paletto et al. 2021; Raha et al. 2020). The global reported data on biodiversity and carbon stocks in forest ecosystems suggest a proportional relationship. A positive linkage between diversity conservation and carbon stock in Russia was reported (Paletto et al. 2021), highlighting the connection between the two parameters. Moreover, a relationship between forest biomass and orchid diversity in a semi-deciduous rain forest of Cameroon was established (Cedric et al. 2021). Thus, understanding the link between biodiversity and forest carbon stocks in dry tropical forests is vital for developing proper conservation strategies (Raha et al. 2020).

The launching of forest-based climate mitigation schemes like the Global Environmental Facility, Clean Development Mechanism, and Reduced Emissions from Deforestation and Forest Degradation has heightened the interest of environmentalists in the estimation of carbon storage (Thokchom, Yadava 2017; Raha et al. 2020). Estimating carbon storage in forest ecosystems for climate management has become a hot topic in the current world 
(Pradhan et al. 2019). As a result, inventories of such data are urgently required to understand forest ecosystem dynamics (Sheikh et al. 2020). Among forest ecosystems, India's dry tropical forests are important carbon and biomass sinks (Kothandaraman et al. 2020; Sheikh et al. 2020). They account for around $40 \%$ of the carbon stored in terrestrial biomass (Raha et al. 2020). They play an important role in preventing global warming and alleviating the negative effects of climate change (Kothandaraman et al. 2020; Kumar et al. 2021). According to the India State of Forest Report (FSI 2019), approximately 7124.6 million tons of carbon are stored in forests of India. Nevertheless, this amount is still small; therefore, to achieve greater potential stocks, the country has committed to expand forest cover by creating an additional 2.5 to 3 billion tons of sequestered carbon by 2030 (FSI 2019). The commitments are under the India's Nationally Determined Contribution (Gandhi, Sundarapandian 2017). One strategy for achieving this goal is to increase forested area of Reserves (FSI 2019). As a result, the inventory of carbon storage in the tropics, including the dry tropics, has become a point of interest. Moreover, currently, India ranks $10^{\text {th }}$ in terms of global forest cover, with approximately 69.1 million hectares of forests (Dibaba et al. 2019; Raha et al. 2020). They represent a diverse range of forest types with high carbon storage potential and biodiversity conservation (Raha et al. 2020).

Several studies have reported data on carbon stocks in the country. Tree diversity and forest carbon stock in tropical semi-evergreen forests was studied and a significant atmospheric $\mathrm{CO}_{2}$ capture by forest ecosystem was verified (Giri et al. 2019). Another study focused on estimating carbon stocks in temperate forests dominated by Cedrus deodara along an altitudinal gradient in the Central Himalaya (Sheikh et al. 2020). A decrease of forest carbon stock with altitude was observed. Differences in tree diversity and carbon stock between a wildlife sanctuary and a sacred forest of India were reported (Pradhan et al. 2019). Similarly, the potential stock in three forest types (dry deciduous teak forest, dry deciduous mixed forest, and Boswellia forest) was quantified (Raha et al. 2020). In addition, the contribution of Eucalyptus tereticornis plantations of different ages in North-west India for carbon stocks and sequestration was estimated (Kumar et al. 2021). Furthermore, different quantifiable methods using PALSAR L-band data and field measurements for estimation of on biomass and carbon stocks for conservation were compared (Behera et al. 2016). Tree composition, stand characteristics, and carbon storage variability in Shorea robusta forests under two forest management regimes was investigated in Tripura, India, and it was reported that plantations stored a large amount of carbon (Banik et al. 2018). A study in tropical forests in the Eastern Ghats of India showed a positive correlation between carbon stocks and woody vegetation and basal area (Gandhi, Sundarapandian 2017). Similar data was reported for tropical deciduous forest dominated by Dipterocarpus tuberculatus in Manipur, India (Devi, Yadava 2015), tropical deciduous forests of India (Behera et al. 2017), and forests in Western Ghats, India (Kothandaraman et al. 2020). Despite the significant relationship between biodiversity and the forest carbon stocks reported by these authors, information that correlates biodiversity and carbon in dry tropical reserve forests of India has been somehow ignored in the literature.

The available reported data in the country focuses on quantifying the levels of carbon stocks and mostly on other forest types, neglecting dry tropical reserve forests of Assam, northeast India. The northeastern parts of India, including the state of Assam, are part of the IndoBurma biodiversity hotspot (Thokchom, Yadava 2017). The regions have high biodiversity and exchange high amount of atmospheric $\mathrm{CO}_{2}$ (Gandhi, Sundarapandian 2017). They are acknowledged as a potential repository of considerable amounts of atmospheric $\mathrm{CO}_{2}$ in the climate budget of the biosphere (Kumar et al. 2021). Despite the large area of reserve forests in the state, most of the existing studies have completely disregarded this region. The baseline data linking forest biodiversity attributes to carbon stocking potentials are scarce. The lack of such data provides insufficient ecological information on establishing proper mitigation against biodiversity loss. The need to evaluate this relationship in the present study was seen as an essential undertaking. Thus, a field study was conducted in two dry tropical reserve forests to minimize this knowledge gap. The objectives of the study were: (i) to assess plant diversity and density; (ii) to quantify potential carbon stocks; and (iii) to assess the relationship between biodiversity attributes with carbon stock.

\section{Materials and methods}

\section{Description of the study area}

The present study was conducted in two reserve forests (RF) of Sonitpur district in Assam, India: Balipara and Bhomoraguri reserve forests (Fig. 1). The Bhomoraguri reserve forest was dominated by Tectona grandis, while Shorea robusta trees dominated Balipara reserve forest. The district is located in the northern part of the central Brahmaputra valley between $92^{\circ} 16^{\prime} \mathrm{E}$ and $93^{\circ} 43^{\prime} \mathrm{E}$ and $26^{\circ} 30^{\prime} \mathrm{N}$ to $27^{\circ} 00^{\prime} \mathrm{N}$, with an average elevation of 70 to 75 $\mathrm{m}$ above mean sea level (Nath et al. 2013). Reserve forests in the district account for $17.57 \%$ of the total area (Baruah et al. 2007). The district is bounded north and south by the Himalayan foothills and the Brahmaputra River, respectively (Nath et al. 2013). The district is located in a dry tropical (subtropical) climate and has a monsoon climate. Summers are hot and humid, with an average temperature of $29^{\circ} \mathrm{C}$ ranging from 7 to $36^{\circ} \mathrm{C}$ (Saxena et al. 2014). The rain starts in early April, and the average annual rainfall ranges from 170 to $220 \mathrm{~cm}$, playing an important part in determining the district's climate. Rainfall is heavy, which 


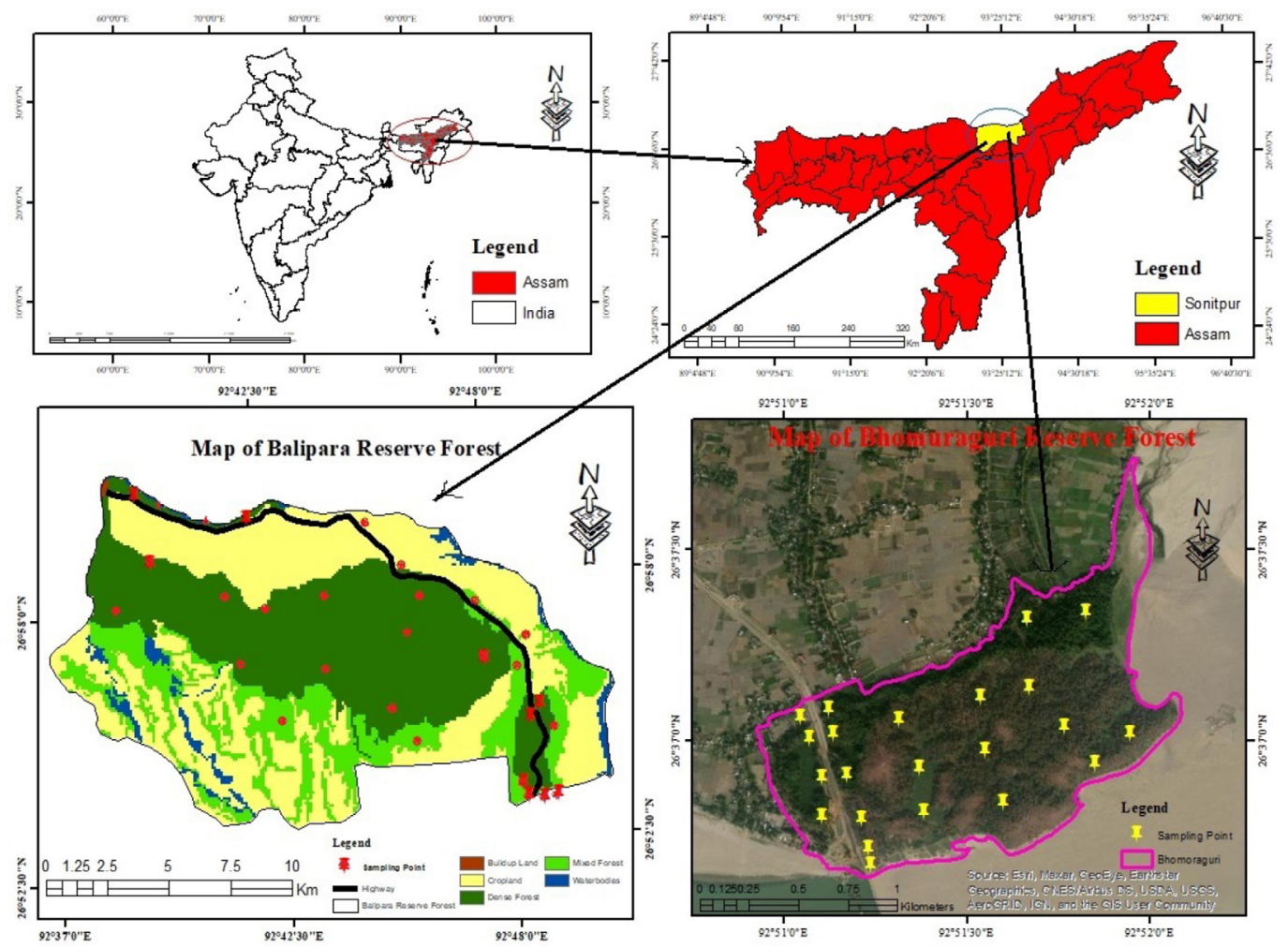

Fig. 1. Maps showing location of Bhomoraguri and Balipara reserve forests of Assam, northeast India.

provides natural irrigation for crops, and sometimes rivers exceed their banks, causing overflow and floods (Baruah et al. 2007; Malunguja et al. 2021).

\section{Vegetation sampling}

A total of 45 permanent circular plots with $15 \mathrm{~m}$ radius (20 in Bhomoraguri RF and 25 in Balipara RF) were systematically established along transects for plant species identification. Subplots of $5 \mathrm{~m}$ radius were established for recording herbaceous species (Brand et al. 1991). Distance between transects was $250 \mathrm{~m}$ and between plots on a transect $-100 \mathrm{~m}$. The plant species present in each plot were identified and recorded based on their local and botanical names with the help of local botanists and floras of India (Shukla 1996; Chowdhury 2005; Mabberley 2008). Herbaria were made for plant species that were difficult to identify in the field and identified at the Ecology and Biodiversity Laboratory, Department of Environmental Science, Tezpur University, India. Phytosociological parameters (frequency, density, height, and diameter at breast height ( $\mathrm{dbh}$ ) were recorded in each plot as follows: (i) within 5-m radius plots, the frequencies of all herbaceous species (grasses, forbs, and climbers) were recorded to assess their composition using quadrat methods (Rubanza et al. 2006); (ii) within $15-\mathrm{m}$ radius plots, all plants with dbh at least $5 \mathrm{~cm}$ were identified and documented as trees. Forked trees were measured separately; height and dbh were measured using Suunto Clinometer (PM-5/360 PC) and a measuring tape, respectively.

\section{Assessment of forest biodiversity attributes}

The frequency $(\mathrm{F})$, abundance $(\mathrm{AB})$, density $(\mathrm{D})$, and basal area (BA) were quantitatively determined using standard forestry inventory methods proposed by Curtis and McIntosh (1950). The importance value index (IVI) was determined by the sum of relative frequency, relative density, and relative dominance (Misra 1989). Within each established plot, four metal frames (quadrat method) with dimension of $0.50 \times 0.50 \mathrm{~m}$ were thrown to record herbaceous species.

Frequency of individuals within a thrown quadrat was determined for all species (Rubanza et al. 2006). If the quadrat fell in a previously sampled location or in a dense shrub layers, the throw was repeated (Czapiewska, Dyderski 2019). Plant diversity measures such as the Shannon-Wiener diversity index $\left(H^{\prime}\right)$, Simpson dominance index $\left(C_{d}\right)$, and evenness were determined following the methods established by Shannon and Weaver (1949), Simpson (1949), and Pielou (1966), respectively:

$$
\begin{gathered}
H^{\prime}=-\sum_{i=1}^{s} p_{i} \ln p_{i}, \\
C_{D}=\sum_{i=1}^{s}\left(p_{i}\right)^{2}, \\
J^{\prime}=H^{\prime} / \operatorname{Ln}(S),
\end{gathered}
$$

where $H^{\prime}$ is the Shannon-wiener diversity index; $P_{i}$ is the proportional abundance of species; $C_{D}$ is Simpson diversity index; and $S$ is species richness. 


\section{Estimation of plant biomass and potential carbon stock}

Herbaceous biomass productivity was determined by the harvest method (Chambers, Brown 1983). It is s a destructive technique that involves clipping off the herbaceous species contained in thrown quadrats at ground level (Saleem et al. 2019). The clipped herbaceous species were immediately transferred to pre-weighed labelled paper bags and instantly weighed for fresh weight using a sensitive weighing balance $( \pm 0.001 \mathrm{~g}$ accuracy). They were labelled and brought to the laboratory, and dried in a forced-air oven at $60{ }^{\circ} \mathrm{C}$ for 48 $\mathrm{h}$ to constant weight to obtain dry matter (DM). The dry matter content was used to estimate the available biomass per unit area (Chambers, Brown 1983):

Herb productivity $=$ Total DM / Total No. of quadrats $\times$ No. of quadrats per area.

A non-destructive approach was used to estimate tree biomass and potential carbon stock. A region specific allometric model developed by Nath et al. (2019) was used: $A G B\left(\mathrm{~kg}\right.$ tree $\left.^{-1}\right)=0.32 \times\left(H \delta D^{2}\right)^{0.75} \times 1.34$,

where $H$ is tree height, $\delta$ is wood density, and $D$ is diameter at breast height.

The model was selected based on its region specificity to India's dry tropical, tropical semi-evergreen, tropical wet evergreen, sub-tropical broad-leaved, and sub-tropical pine forests. The region species-specific allometric equations were adopted to reduce error sources during estimation. This method requires quantitative data like tree height, diameter at breast height (dbh), and wood density (Chave et al. 2014). Tree wood density for species was obtained from the Forest Survey of India report of 1996 (FSI 1996), which were cross-checked with the global wood density database listed by Chave et al. (2009) to ensure validity.

Similarly, estimation of belowground tree biomass (BGB) and total biomass (TB) was calculated following the equations suggested by IPCC (Eggleston et al. 2006):

$$
\begin{aligned}
& B G B\left(\mathrm{~kg} \mathrm{tree}^{-1}\right)=A G B \times 0.26, \\
& T B\left(\mathrm{~kg} \mathrm{tree}^{-1}\right)=A G B+B G B,
\end{aligned}
$$

where $\mathrm{BGB}$ is belowground biomass; TB is total biomass.

Furthermore, the conversion of tree biomass $(T B)$ to carbon stock $(T C)$ was done by multiplying the $T B$ with the Default Carbon Conversion Factor of 0.47 (Eggleston et al. 2006):

$$
T C=T B \times 0.47 .
$$

The amount of $\mathrm{CO}_{2}$ equivalent was estimated by multiplying the total carbon stock $(T C)$ by a factor of 3.67 (Malunguja et al. 2020). The results were reported in tons per hectare $\left(\mathrm{t} \mathrm{ha}^{-1}\right)$ :

$$
\mathrm{CO}_{2} e=T C \times 3.67
$$

where $T C$ is tree carbon and $\mathrm{CO}_{2} e$ is carbon dioxide equivalent potential.

\section{Statistical analysis}

Descriptive statistics were used to represent plant diversity and potential carbon stock data. The Shapiro-Wilk and Levene tests were used to test for normality and homogeneity, respectively. One-way ANOVA was performed to test for significant differences for plant diversity and carbon stocks. Similarly, the Fisher's Least Significant Difference Test was used to determine whether differences between the means were statistically significant at $p=0.05$. Pearson's correlation, regression analysis, and cluster analysis were used to determine relationships, grouping patterns, and the contribution of variables on carbon stocks, respectively. A dendrogram was created using the Ward method, and Euclidean distance was used to depict the patterns of clusters. An independent $t$-test with a significance level of 0.05 was used to test for significant differences between the two reserve forests. All statistical analyses were performed using the SPSS Software program (ver. 20.0; SPSS, Chicago, IL).

\section{Results}

\section{Biodiversity attributes}

A total of 95 plant species ( 31 trees, 42 forbs, 13 grasses, and nine climbers) belonging to 89 genera and 49 families were recorded in the Bhomoraguri reserve forest. In the Balipra reserve forest, a total of 91 plant species $(42$ trees, 29 forbs, 10 grasses, and 10 climbers) belonging to 86 genera and 56 families were recorded. Biodiversity attributes such as stand density, richness, diversity number of genera, and families of species categories are presented in Table 1 . The overall forest stand density analysis showed that the number of individual plant species per unit area (individuals $\mathrm{ha}^{-1}$ ) was significantly different within and across forests $(p<0.05)$. In all studied RFs, forb species had highest density of individuals per hectare. A total of 120 400000 and 90080000 individual forbs (individuals ha ${ }^{-1}$ ) were recorded in Bhomoraguri reserve forest and Balipara reserve forest, respectively. Moreover, the lowest number of individuals per ha was among tree species -4480 and 4822 in Bhomoraguri reserve forest and Balipara reserve forest, respectively. Number of individuals in different plant growth forms (i.e., grasses, forbs, climbers, and trees) significantly differed $(p=0.001)$.

Based on the importance value index (IVI), the dominant plant species in Bhomoraguri reserve forest were Cynodon dactylon (40.27), Datura stramonium (20.21), Clitoria ternatea (50.20) and Tectona grandis (58.34) for grasses, forbs, climbers, and trees, respectively (Table 1). In Balipara RF the dominant species were Cymbopogon nardus (49.08), Colocasia esculenta (22.42), Mikania micrantha (50.26), and Shorea robusta (121.36) for grasses, forbs, climbers, and trees, respectively. Other plant species with relatively high IVI values in Bhomoraguri RF included Imperata cylindrica (35.81), Brachiaria reptans (33.56), and Axonopus compressus (26.15) for grasses; Chromolaena odorata (14.93), Alternanthera sessilis (13.39), and Hydrocotyle sibthorpioides (13.11) for herbs; Piper betle (51.30), Cissus rotundifolia (42.60), and Paederia foetida (40.80) for climbers; and Artocarpus integer (25.28), Ficus carica (25.09), and Dalbergia sissoo (21.34) for trees. In 
Table 1. Diversity indices and dominant plant species recorded in Bhomoraguri and Balipara reserve forests, Assam India. S1, Bhomoraguri reserve forest; S2, Balipala reserve forest; D, density of plant species (individuals ha ${ }^{-1}$ ); SR, species richness; H, ShannonWiener diversity index; C, Simpson's index; J', Pielou's index of evenness; NG, number of genera; NF, number of families

\begin{tabular}{|c|c|c|c|c|c|c|c|c|c|}
\hline Forest & $\begin{array}{l}\text { Plant } \\
\text { category }\end{array}$ & Four dominant plant species (IVI ) & D & SR & $\mathbf{H}^{\prime}$ & C & $\mathbf{J}^{\prime}$ & NG & NF \\
\hline \multirow[t]{4}{*}{ S1 } & Grasses & $\begin{array}{l}\text { Cynodon dactylon (L.) Pers (40.27), } \\
\text { Imperata cylindrica (Linn.) Beauv } \\
(35.81) \text {, Brachiaria reptans (L.) (33.56), } \\
\text { Axonopus compressus (Sw.) P.Beauv } \\
(26.15)\end{array}$ & 30360000 & 13 & 2.34 & 0.12 & 0.91 & 13 & 2 \\
\hline & Forbs & $\begin{array}{l}\text { Datura stramonium L. (20.21), } \\
\text { Chromolaena odorata (L.) RM (14.93), } \\
\text { Alternanthera sessilis L. (13.39), } \\
\text { Hydrocotyle sibthorpioides Lam. (13.11) }\end{array}$ & 120400000 & 42 & 3.42 & 0.14 & 0.90 & 39 & 20 \\
\hline & Climbers & $\begin{array}{l}\text { Clitoria ternatea L. (50.20), Piper betle } \\
\text { L. (51.30), Cissus rotundifolia Vahl } \\
(42.60), \text { Paederia foetida L. }(40.80)\end{array}$ & 23840000 & 9 & 2.06 & 0.34 & 0.93 & 08 & 7 \\
\hline & Trees & $\begin{array}{l}\text { Tectona grandis L.f. (58.34)., Artocarpus } \\
\text { integer (Thunb.) Merr. (25.28), Ficus } \\
\text { carica L. (25.09), Dalbergia sissoo Roxb. } \\
(21.34)\end{array}$ & 4480 & 31 & 4.98 & 0.17 & 0.03 & 29 & 20 \\
\hline \multirow[t]{4}{*}{ S2 } & Grasses & $\begin{array}{l}\text { Cymbopogon nardus (L.) Rendle } \\
\text { (49.08), Cynodon dactylon (L.) Pers. } \\
\text { (41.72), Imperata cylindrica (Linn.) } \\
\text { Beauv. (38.78), Cyperus rotundus L. } \\
\text { (37.81) }\end{array}$ & 27840000 & 10 & 2.17 & 0.13 & 0.94 & 10 & 2 \\
\hline & Forbs & $\begin{array}{l}\text { Colocasia esculenta (L.) Schott (22.42), } \\
\text { Chromolaena odorata (L.) R.M.King } \\
\text { (17.97), Drymaria cordata (17.05), } \\
\text { Galinsoga parviflora Cav. (16.01) }\end{array}$ & 90080000 & 29 & 3.13 & 0.06 & 0.92 & 28 & 20 \\
\hline & Climbers & $\begin{array}{l}\text { Mikania micrantha Kunth. (50.26), } \\
\text { Hedyotis scandens Roxb. (46.26), } \\
\text { Ipomea eriocarpa (43.36), Centrosema } \\
\text { brasilianum (L.) Benth. (33.60) }\end{array}$ & 27440000 & 10 & 2.11 & 0.14 & 0.91 & 8 & 8 \\
\hline & Trees & $\begin{array}{l}\text { Shorea robusta Roth (121.36), Syzygium } \\
\text { cumini (L.) Skeels. (28.18), Kayea } \\
\text { floribunda Wall. (26.10), Ficus carica } \\
\text { L. (20.34) }\end{array}$ & 4822 & 42 & 2.70 & 0.17 & 0.01 & 40 & 26 \\
\hline
\end{tabular}

Balipara reserve forest, species with a relatively high IVI value for herbs were Hedyotis scandens (46.26); Ipomea eriocarpa (43.36), and Centrosema brasilianum (33.60) for climbers; Syzygium cumini (28.18), Kayea floribunda (26.10) and Ficus carica (20.34) for trees.

The Shannon-Weaver diversity index differed between reserve forests. Tree species had higher diversity $\left(H^{\prime}=\right.$ 4.98) in Bhomoraguri reserve forest than forbs $\left(H^{\prime}=3.42\right)$ and climbers $\left(H^{\prime}=2.06\right)$. In Balipala reserve forest, forb species were more diverse $\left(H^{\prime}=3.13\right)$ than other plant categories $\left(H^{\prime}=2.11\right.$ for climbers, $\mathrm{H}^{\prime}=2.17$ for grasses, and $H^{\prime}=2.70$ for trees). The higher diversity index of trees in Bhomoraguri RF indicated that the dominant tree (Tectona grandis) did not suppress other plant species causing a decrease in their density. In contrast, in Balipara reserve forest, the occupied niche of the dominant Shorea robusta tree did not allow coexistence with other tree species.

\section{Plant species biomass production and potential carbon stock}

Descriptive information (mean, standard deviation, and sum) on plant species biomass and potential carbon stock are given in Table 2. The total plant species biomass in Bhomoraguri reserve forest was $302.93 \mathrm{t} \mathrm{ha}^{-1}$ (13.62 for grasses; 64.69 for forbs; 58.61 for climbers; 166.01 for trees). In Balipara reserve forest, biomass was $283.97 \mathrm{t}$ ha $^{-1}$ (8.05 for grasses; 69.22 for forbs; 69.36 for climbers; 137.34 for trees). The recorded biomass was equivalent to approximately $555.87 \mathrm{t} \mathrm{ha}^{-1}$ and $521.30 \mathrm{t} \mathrm{ha}^{-1} \mathrm{CO}_{2}$ equivalents sequestered in Bhomoraguri and Balipara reserve forests, respectively. Tree species contributed the most biomass and carbon stock (54.80\%), followed by forbs (21.36\%) and grasses (4.49\%) in Bhomoraguri reserve forest. Similarly, in Balipara reserve forest, trees accounted for the majority of biomass production (48.34\%), followed 
Table 2. Descriptive statistics (mean, $\mathrm{SD}$ and total) for plant carbon stocks ( $\mathrm{t} \mathrm{ha} \mathrm{a}^{-1}$ ) in Bhomoraguri and Balipara reserve forest, Assam, India. AGB, aboveground biomass; $\mathrm{BGB}$, belowground biomass; TB, total biomass; TC, carbon stocks; $\mathrm{CO}_{2} \mathrm{e}$, carbon dioxide equivalent; $\mathrm{SD}$, standard deviation

\begin{tabular}{|c|c|c|c|c|c|c|c|c|c|c|c|}
\hline \multirow[t]{2}{*}{ Parameters } & \multirow[t]{2}{*}{ Statistics } & \multicolumn{5}{|c|}{ Bhomoraguri RF } & \multicolumn{5}{|c|}{ Balipara RF } \\
\hline & & Grasses & Forbs & Climbers & Trees & Total & Grasses & Forbs & Climbers & Trees & Total \\
\hline \multirow[t]{3}{*}{$\mathrm{ABG}$} & Mean & 4.16 & 2.76 & 6.51 & 4.25 & & 0.82 & 2.39 & 6.94 & 2.6 & \\
\hline & $\mathrm{SD}$ & 0.58 & 0.89 & 1.66 & 0.59 & & 0.15 & 0.46 & 1.11 & 0.58 & \\
\hline & Sub-total & 13.62 & 64.69 & 58.61 & 131.75 & 268.67 & 8.05 & 69.22 & 69.36 & 109.01 & 255.64 \\
\hline \multirow[t]{3}{*}{ BGB } & Mean & - & - & - & 1.11 & & - & - & - & 0.67 & \\
\hline & $\mathrm{SD}$ & - & - & - & 0.15 & & - & - & - & 0.15 & \\
\hline & Sub-total & - & - & - & 34.25 & 34.25 & - & - & - & 28.34 & 28.34 \\
\hline \multirow[t]{3}{*}{ TB } & Mean & 4.16 & 2.76 & 6.51 & 5.35 & & 0.82 & 2.39 & 6.94 & 3.27 & \\
\hline & $\mathrm{SD}$ & 0.58 & 0.89 & 1.66 & 0.75 & & 0.15 & 0.46 & 1.11 & 0.73 & \\
\hline & Sub-total & 13.62 & 64.69 & 58.61 & 166.01 & 302.93 & 8.05 & 69.22 & 69.36 & 137.34 & 283.97 \\
\hline \multirow[t]{3}{*}{ TC } & Mean & 0.52 & 0.77 & 3.26 & 2.68 & & 0.4 & 1.19 & 3.47 & 1.64 & \\
\hline & $\mathrm{SD}$ & 0.12 & 0.08 & 0.83 & 0.37 & & 0.07 & 0.23 & 0.56 & 0.37 & \\
\hline & Sub-total & 6.81 & 32.35 & 29.31 & 83 & 151.47 & 4.03 & 34.61 & 34.68 & 68.67 & 141.99 \\
\hline \multirow[t]{3}{*}{$\mathrm{CO} 2 \mathrm{e}$} & Mean & 1.92 & 2.83 & 11.95 & 9.83 & & 1.48 & 4.38 & 12.73 & 6 & \\
\hline & $\mathrm{SD}$ & 0.44 & 0.3 & 3.05 & 1.36 & & 0.27 & 0.84 & 2.04 & 1.34 & \\
\hline & Sub-total & 24.98 & 118.72 & 107.55 & 304.62 & 555.87 & 14.97 & 127 & 127.28 & 252.03 & 521.3 \\
\hline
\end{tabular}

by climbers (24.42\%), forbs (24.37\%), and grasses (2.87\%). Analysis of variance revealed that the biomass and potential carbon stock of plant growth forms (trees, grasses, forbs, and climbers) differed considerably ( $p<0.05$; Table 3 ), indicating that also productivity and potential stock of plant species differed greatly among plant growth forms. Similarly, post-hoc analyses employing the Fisher's Least Significant Difference demonstrated significant variation in potential biomass stock among trees, grasses, forbs, and climbers at $\mathrm{F}_{3,91}=16.37, p=0.000$ and $\mathrm{F}_{3,87}=5.21, p=0.002$, for Bhomoraguri reserve forest and Balipara reserve forest, respectively. However, the comparison of the two studied forests using an independent t-tes, revealed no statistically significant difference in biomass production $(t=0.229, d f$ $=182, p=0.819$ ).

The first top ten tree species with highest biomass ( $\mathrm{t}$ $\mathrm{ha}^{-1}$ ) in Bhomoraguri RF were Tectona grandis (19.18), Artocarpus integer (12.35), Dalbergia sissoo (11.87), Ficus carica (9.4), Albizia lucidor (9.23), Duabanga grandiflora (8.52), Dillenia indica (7.61), Gmelina arborea (7.55), Bombax ceiba (7.03), and Morus laevigata (6.57) (Table 4). In Balipara RF, the highest biomass was for Ficus carica (25.2), Mimusops elengi (17.09), Stereospermum chelonoides (9.99), Phyllanthus distichus (8.43), Altingia excelsa (6.49),

Table 3. Multiple comparisons using Fisher's Least Significant Difference Test and independent $t$-test results on comparing carbon stocks among plant categories and two sites, respectively

\begin{tabular}{|c|c|c|c|}
\hline \multicolumn{2}{|c|}{$\begin{array}{l}\text { Plant categories } \\
\text { Multiple comparisons using LSD }\end{array}$} & $\begin{array}{l}\text { Bhomoraguri RF } \\
\text { Significance }\end{array}$ & $\begin{array}{l}\text { Balipara RF } \\
\text { Significance }\end{array}$ \\
\hline \multirow[t]{3}{*}{ Trees } & Grasses & 0.000 & 0.063 \\
\hline & Forbs & 0.000 & 0.328 \\
\hline & Climbers & 0.298 & 0.006 \\
\hline \multirow[t]{3}{*}{ Grasses } & Trees & 0.000 & 0.063 \\
\hline & Forbs & 0.596 & 0.249 \\
\hline & Climbers & 0.000 & 0.000 \\
\hline \multirow[t]{3}{*}{ Forbs } & Trees & 0.000 & 0.328 \\
\hline & Grasses & 0.596 & 0.249 \\
\hline & Climbers & 0.000 & 0.001 \\
\hline \multirow[t]{3}{*}{ Climbers } & Trees & 0.298 & 0.006 \\
\hline & Grasses & 0.000 & 0.000 \\
\hline & Forbs & 0.000 & 0.001 \\
\hline \multicolumn{2}{|c|}{ Overall ANOVA results: } & $\mathrm{F}_{3,91}=16.368, p=0.000$ & $\mathrm{~F}_{3,87}=5.206, p=0.002$ \\
\hline \multicolumn{2}{|c|}{$\begin{array}{l}\text { Independent } t \text {-test results between Bhomoraguri and } \\
\text { Balipara RF: }\end{array}$} & \multicolumn{2}{|c|}{$t=0.229 ; d f=182 ; p=0.819$} \\
\hline
\end{tabular}


Table 4. Tree species recorded the top 10 biomass and carbon stocking potential in Bhomoraguri and Balipara RFs

\begin{tabular}{|c|c|c|c|c|c|}
\hline \multirow[t]{2}{*}{ Forest } & \multirow[t]{2}{*}{ Botanical name } & \multirow[t]{2}{*}{ Family } & \multicolumn{3}{|c|}{ Biomass stocks $\left(\mathrm{t} \mathrm{ha}^{-1}\right)$} \\
\hline & & & TB & C stock & $\mathrm{CO}_{2} \mathrm{e}$ \\
\hline \multirow[t]{10}{*}{ Bhomoraguri } & Tectona grandis L.f. & Verbenaceae & 19.18 & 9.59 & 35.20 \\
\hline & Artocarpus integer (Thunb.) Merr. & Moraceae & 12.35 & 6.18 & 22.67 \\
\hline & Dalbergia sissoo Roxb. & Fabaceae & 11.87 & 5.93 & 21.77 \\
\hline & Ficus carica L. & Moraceae & 9.40 & 4.70 & 17.25 \\
\hline & Albizia lucidor (Steud.) I.C.Nielsen & Fabaceae & 9.23 & 4.61 & 16.93 \\
\hline & Duabanga grandiflora Roxb. & Lythraceae & 8.52 & 4.26 & 15.63 \\
\hline & Dillenia indica $\mathrm{L}$. & Dilleniaceae & 7.61 & 3.81 & 13.97 \\
\hline & Gmelina arborea Roxb. & Lamiaceae & 7.55 & 3.77 & 13.85 \\
\hline & Bombax ceiba L. & Malvaceae & 7.03 & 3.51 & 12.89 \\
\hline & Morus laevigata Wall. & Moraceae & 6.57 & 3.29 & 12.06 \\
\hline \multirow[t]{10}{*}{ Balipara } & Ficus carica L. & Moraceae & 25.20 & 12.60 & 46.24 \\
\hline & Mimusops elengi L. & Sapotaceae & 17.09 & 8.54 & 31.35 \\
\hline & Stereospermum chelonoides DC. & Bignoniaceae & 9.99 & 5.00 & 18.33 \\
\hline & Phyllanthus distichu Müll.Arg. & Phyllanthaceae & 8.43 & 4.22 & 15.48 \\
\hline & Altingia excelsa Noronha & Altingiaceae & 6.49 & 3.25 & 11.91 \\
\hline & Shorea robusta Roth. & Dipterocarpaceae & 6.42 & 3.21 & 11.79 \\
\hline & Millettia pinnata (L. Panigrahi & Fabaceae & 6.28 & 3.14 & 11.52 \\
\hline & Sterculia villosa Roxb. ex Sm. & Malvaceae & 4.35 & 2.18 & 7.99 \\
\hline & Ficus elastica Roxb. ex Hornem & Moraceae & 4.25 & 2.13 & 7.81 \\
\hline & Baccaurea ramiflora Lour. & Phyllanthaceae & 3.80 & 1.90 & 6.97 \\
\hline
\end{tabular}

Michelia champaca (6.42), Millettia pinnata (6.28), Sterculia villosa (4.35), Ficus elastica (4.25), and Baccaurea ramiflora (3.80). Consequently, these results show promising carbon storage capacity for decreasing atmospheric carbon dioxide through carbon sequestration.

\section{Relationships between diversity, density and potential carbon stock}

The Pearson correlation coefficient was used to evaluate the correlations between species diversity, density, and potential carbon stock (Table 5). The density of tree and climber species had a positive correlation with carbon stock $(r=0.74 ; p=0.000$ for trees, and $r=0.85 ; p=0.003$ for climbers). Grass density and forb density were associated negatively with carbon stock: $r=-0.32 ; p=0.23$ for grasses, and $r=-0.14 ; p=0.38$ for forbs. Species diversity $\left(H^{\prime}\right)$ was strongly positively correlated with forest carbon stock $(r=$ $0.75 ; p=0.000$ for trees, $r=0.78 ; p=0.014$ for climbers, and $r=0.96 ; p=0.000$ for forbs. However, there was a negative correlation with grass species $(r=-0.48 ; p=0.090)$ in Bhomoraguri reserve forest. A similar positive correlation between diversity of trees, climbers, and forbs with carbon stock was also observed in Balipara reserve forest. In contrast, grass density had negative correlation with carbon stock (Table 5). Thus, density and diversity had significant positive association with biomass stock for tree and climber species, implying that they have positive effect on carbon stocks. On the other hand, the density and diversity of grasses are inversely related to the biomass stock, negatively affecting potential forest stock. Additionally, thre was a negative relationship between the density and carbon stock for grass species: $R^{2}=0.81$ and $R^{2}=0.93$ for Bhomoraguri Reserve Forest, and Balipara reserve forest, respectively (Fig. 2).

Hierarchal cluster analysis was employed to explore the associations between the analyzed parameters. The dendrogram results in Fig. $3 \mathrm{~A}$ and $\mathrm{B}$ show clustering of biodiversity attributes and carbon stocking potential. The Ward approach with rescaled distance cluster combined method revealed similar patterns as observed in the correlation analysis. Groups of related parameters emerged. Hierarchal cluster analysis divided the parameters into two primary clusters (groups) for Bhomoraguri reserve forest, each with its unique set of characteristics (Fig 3A). Forb diversity; forb density; grass diversity; grass density; climber diversity, density, and climber carbon stocks formed cluster one. The second cluster was formed by tree diversity, density, and tree carbon stock; grass carbon stock and forb carbon stock. The first cluster was further divided into three sub-groups; the first sub-group contained forb diversity; forb density, while the second sub-group was made up of grass diversity and grass density. The third sub-group included climber diversity, density, and climber carbon stocks. A similar trend was also observed for Balipara RF (Fig. 3B). The relationships and grouping found in the cluster analysis supported the relationships observed in correlation analysis.

A stepwise regression analysis determined each predictor's contribution for biomass and potential carbon stock. The results indicated association between the density 
Table 5. Correlation between biodiversity attributes and carbon stocks in Bhomoraguri and Balipara reserve forest. ${ }^{\star}$, correlation is significant at the 0.05 level (2-tailed); ${ }^{* *}$, correlation is significant at the 0.01 level (2-tailed). TB, GB, FB, \& CB are tree, grass, forb, and climber biomass, respectively; TD, GD, FD, CD are tree, grass, forb, and climber density, respectively; TH, GH, FH \& CH are tree, grass, forb, and climber diversity, respectively

$\begin{array}{lcccccccccccc} & \text { TB } & \text { GB } & \text { FB } & \text { CB } & \text { TD } & \text { GD } & \text { FD } & \text { CD } & \text { TH } & \text { GH } & \text { FH } & \text { CH } \\ \text { Bhomoraguri reserved forest } & & & & & & & & & & & \\ \text { TB } & 1 & 0.204 & 0.143 & 0.194 & 0.734^{* *} & 0.003 & -0.080 & 0.347 & 0.745^{* *} & 0.129 & -0.007 & 0.372 \\ \text { GB } & & 1 & -0.016 & -0.308 & -0.106 & -0.324 & -0.050 & -0.356 & -0.081 & -0.478 & -0.024 & -0.368 \\ \text { FB } & & & 1 & -0.340 & 0.034 & 0.070 & -0.141 & -0.461 & 0.046 & 0.109 & 0.964^{* *} & -0.510 \\ \text { CB } & & & & 1 & -0.023 & -0.257 & 0.468 & 0.854^{* *} & -0.014 & -0.277 & 0.455 & 0.777^{*} \\ \text { TD } & & & & & 1 & 0.158 & -0.022 & 0.162 & 0.888^{* *} & 0.256 & 0.017 & 0.202 \\ \text { GD } & & & & & & 1 & 0.316 & -0.220 & 0.107 & 0.966^{* *} & 0.344 & -0.173 \\ \text { HD } & & & & & & & 1 & 0.106 & -0.092 & 0.325 & 0.988^{* *} & 0.047 \\ \text { CD } & & & & & & & & 1 & 0.128 & -0.216 & 0.090 & 0.988^{* *} \\ \text { TH } & & & & & & & & & 1 & 0.199 & -0.049 & 0.157 \\ \text { GH } & & & & & & & & & 1 & 0.348 & -0.161 \\ \text { FH } & & & & & & & & & & 1 & 0.029 \\ \text { CH } & & & & & & & & & & & & 1\end{array}$

Balipara reserved forest

\begin{tabular}{|c|c|c|c|c|c|c|c|c|c|c|c|}
\hline TB & 1 & & & & & & & & & & \\
\hline GB & 0.242 & 1 & & & & & & & & & \\
\hline FB & -0.188 & 0.115 & 1 & & & & & & & & \\
\hline $\mathrm{CB}$ & -0.184 & 0.300 & 0.226 & 1 & & & & & & & \\
\hline TD & 0.041 & 0.011 & -0.066 & -0.045 & 1 & & & & & & \\
\hline GD & -0.354 & -0.352 & -0.31 & 0.161 & 0.336 & 1 & & & & & \\
\hline FD & -0.106 & 0.14 & -0.024 & -0.116 & -0.184 & -0.130 & 1 & & & & \\
\hline $\mathrm{CD}$ & -0.427 & 0.089 & 0.513 & $0.680^{*}$ & -0.269 & -0.059 & 0.493 & 1 & & & \\
\hline $\mathrm{TH}$ & 0.083 & 0.022 & -0.069 & -0.049 & $0.900^{* *}$ & 0.264 & -0.191 & -0.245 & 1 & & \\
\hline GH & -0.208 & -0.42 & -0.324 & 0.154 & 0.195 & $0.969^{\star *}$ & -0.036 & 0.020 & 0.129 & 1 & \\
\hline FH & 0.080 & 0.176 & 0.001 & -0.223 & -0.194 & -0.180 & $0.982^{* *}$ & 0.399 & -0.200 & -0.088 & 1 \\
\hline $\mathrm{CH}$ & -0.426 & 0.198 & 0.543 & $0.763^{\star}$ & -0.314 & -0.133 & 0.378 & $0.979^{\star *}$ & -0.289 & -0.067 & 0.285 \\
\hline
\end{tabular}

and diversity of trees and climbers on carbon stock, with the varying models (Table 6). Biodiversity attributes accounted for approximately $91.8,58.01,51.3$, and $11.11 \%$ of the variance for climbers, trees, grasses and forbs, respectively. The unique contributions of each predictor differed greatly: $\beta=3.65, t=4.81, p=0.003$ for climber density; and $\beta=$ $-2.83, t=-3.73, p=0.010$ for climber diversity; for grass density $(\beta=-2.07, t=2.42, p=0.036)$; grass diversity $(\beta$ $=-2.48, t=-2.90, p=0.016)$; forb density $(\beta=-2.08, t=$ $-2.12, p=0.041)$. However, no significant difference was observed for tree density $(\beta=0.34, t=1.29, p=0.207)$; for tree diversity $(\beta=0.44, t=1.65, p=0.110)$ and forb diversity $(\beta=1.97, t=1.99, p=0.053)$. The findings imply that density and diversity are important predictors of plant biomass and carbon stocks in forest ecosystems. A better understanding of the relationships between biodiversity attributes, biomass and carbon

\section{Discussion}

\section{Biodiversity attributes}

The present findings revealed a relatively low plant species density that differed considerably among plant growth forms. Tree species had significantly higher diversity in Bhomoraguri RF, while climbers had the lowest diversity. Nevertheless, forbs had the largest diversity in Balipara RF, followed by trees, while climbers had the lowest diversity. The reported diversity values imply significant low vegetation cover in the studied reserve forests. The present study observed great dominance of species like P. betle and S. ovalifolia, which exhibited weed traits by higher density and frequency, and were little affected by effects of the tree canopy.

The frequency and abundance of grass species such as Aristida spp., and Cenchrus spp. are good indicators of disturbed ecosystems with high regeneration potential under adverse conditions (Rubanza et al. 2006). Other species, such as I. cheirophylla and Sida spp., clearly indicate disturbed habitats. The dominance of these species indicates the presence of numerous types of humaninduced disturbances such as forest encroachment, forest fires, grazing, fuel-wood procurement, medicinal herb harvesting, and exploitation. Anthropogenic activities may have a significant effect on plant species composition. On the other hand, species like H. sibthorpioides and $C$. dactylon are water-loving species. The frequent floods in 

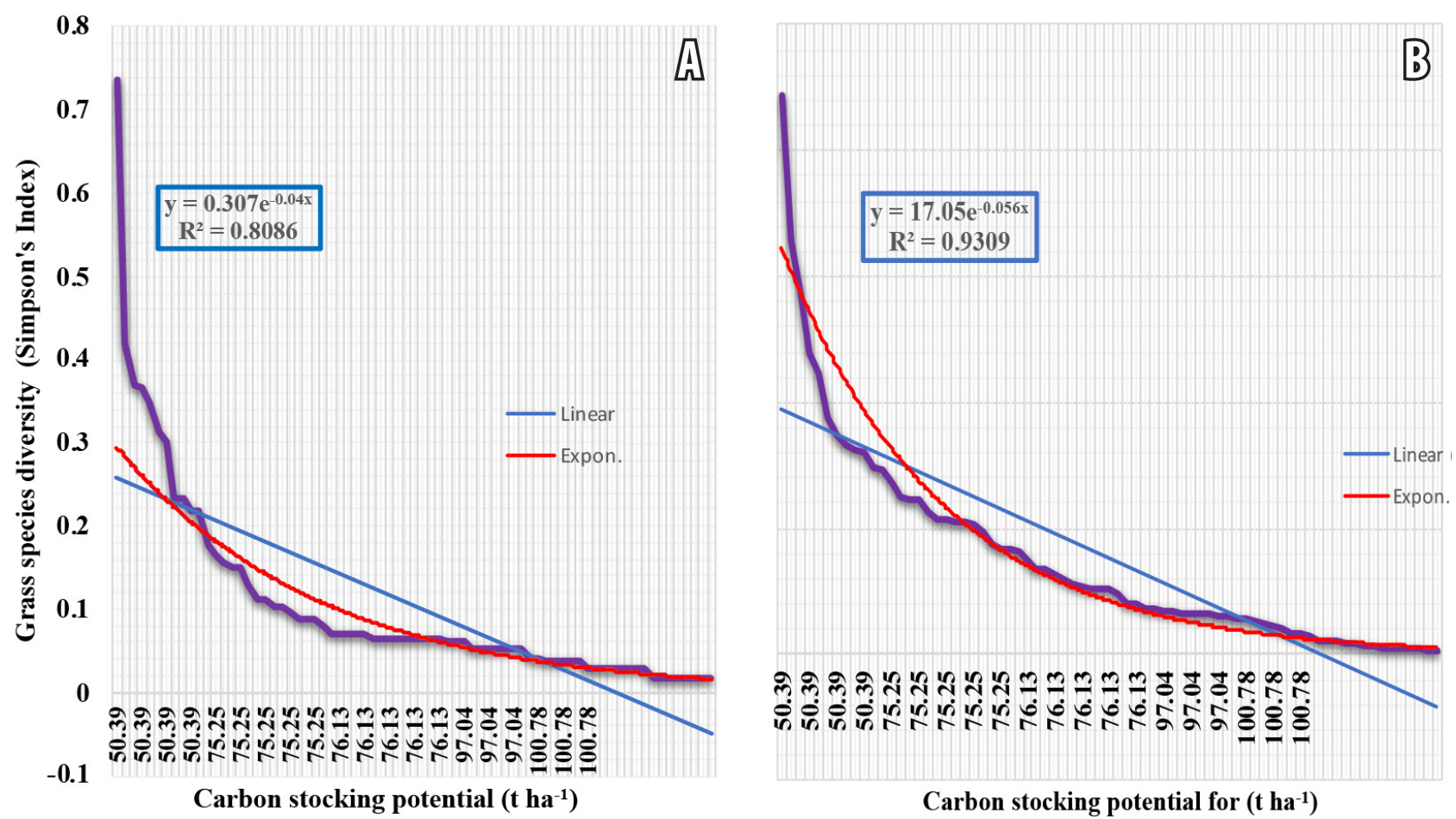

Fig. 2. Relationship between grass species diversity and carbon stocking potential for grasses in Bhomoraguri (A) and Balipara (B) reserve forests.

the forests could have influenced water-loving plants to colonize and thrive. The greater number of understory species recorded in Balipara RF than Bhomoraguri RF, could be due to fewer tall trees with less canopy, favoring recovery and growth of understory species. L. camara, which is dominant in Bhomoraguri, is a notorious plant that suppresses the establishment and development of other understory species. The dominance of species like $L$. camara is frequent in northeast India's dry and damp forests (Naveenkumar et al. 2017). It is an aggressive colonizer, especially near forest borders with disturbed ecosystems. The presence of anthropogenic disturbances is due to the growing population over the previous few decades. The high population size has resulted in extensive exploitation of natural resources, placing forest biodiversity under severe anthropogenic stress. High anthropogenic stress
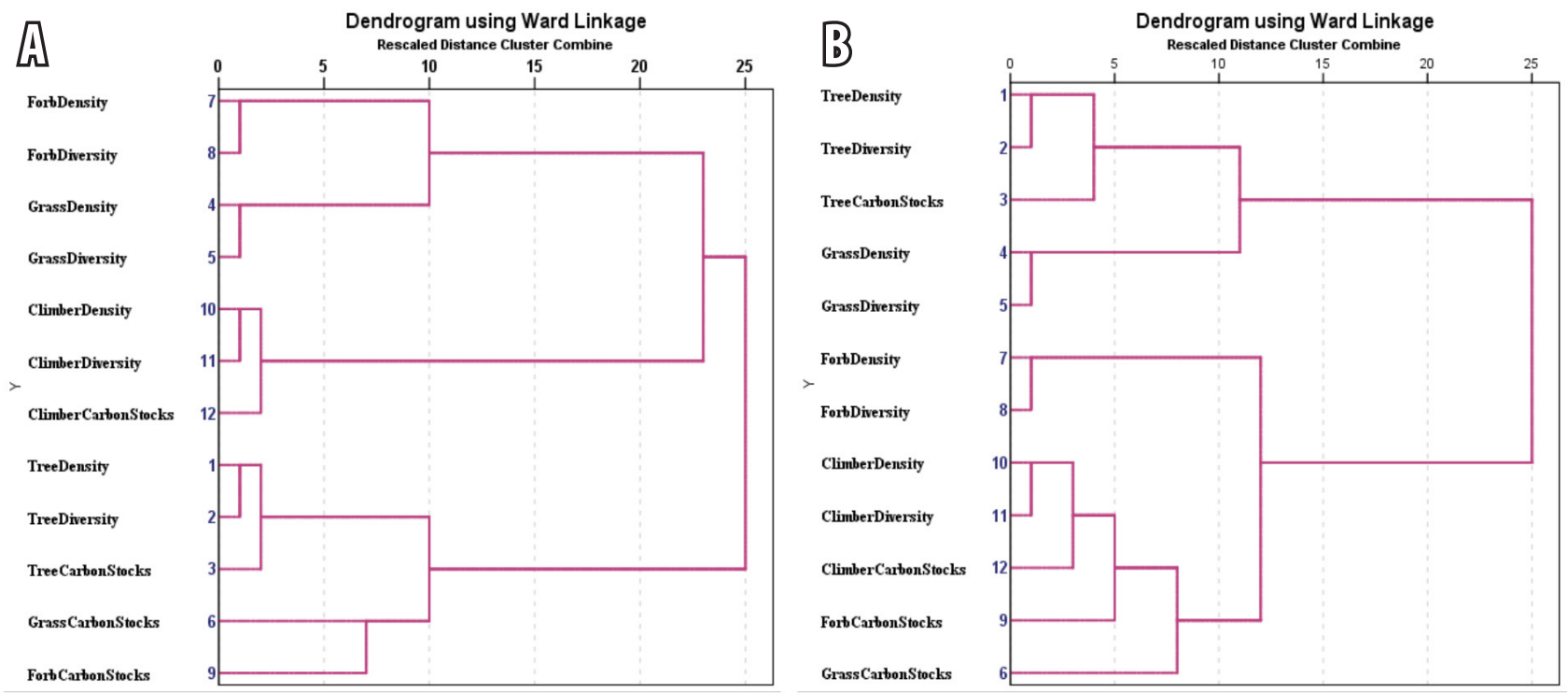

Fig. 3. Hierarchical dendrogram depictsing biodiversity attributes and carbon stock clusters for Bhomotaguri RF (A) and Balipara RF (B). 
Table 6. Regression model to predict the effects of biodiversity attributes on forest carbon stocking potential. $\hat{Y} s$, dependent variable (biomass stocks from herbaceous and trees); $H^{\prime}$, species diversity; $D$, species density; E, a mathematical expression of an exponent

$\begin{array}{llccc}\text { Category } & \text { Predictors } & \text { Regression equations } & R \text { square } & \text { Significance } \\ \text { Grasses } & \text { Diversity \& density } & \hat{Y} s=3.91+\left(-29.11 H^{\prime}\right)+1.02 \mathrm{E}-0.06 D & R^{2}=0.51 & p=0.027 \\ \text { Forbs } & \text { Diversity \& density } & \hat{Y} s=0.74+41.48 H^{\prime}+(-9.00 \mathrm{E}-0.07 D) & R^{2}=0.11 & p=0.101 \\ \text { Climbers } & \text { Diversity \& density } & \hat{Y} s=22.35+\left(-205.84 H^{\prime}\right)+1.17 \mathrm{E}-0.05 D & R^{2}=0.92 & p=0.001 \\ \text { Trees } & \text { Diversity \& density } & \hat{Y} s=2.77+11.85 H^{\prime}+0.005 D & R^{2}=0.58 & p<0.001\end{array}$

could have contributed to the poor diversity of grasses and climbers in Bhomoraguri RF. Thus, the high level of human invasion in these forests requires attention. Most reserve forests might become degraded landscapes shortly unless proper mitigation against human encroachment is made (Gogoi, Sahoo 2018).

Although the Shannon-Weaver diversity index values obtained in this study were within the range of 1.85 to 5.68 reported previously from India's dry tropical forests (Pradhan et al. 2019), the number of individual species and overall plant species diversity in the present study were low compared to other tropical and dry tropical forests of India. For example, the present study's findings are inconsistent with Baruah et al. (2013) and Begum et al. (2011), whose numbers were comparatively larger. The findings of the present study, on the other hand, agree with those published by Dutta and Devi (2013), Gogoi, Sahoo (2018), Nohro, Jayakumar (2020), and higher number of individual plant species than the reported data by Konwar et al. (2009) and Sarkar and Devi (2014).

\section{Plant biomass and potential carbon stock}

Biomass and carbon stock from the present study differed significantly among plant growth forms within the forest but did not differ between forests. Tree species contributed the most carbon stock across both forests (i.e., 54.80 and 48.34\% for Bhomoraguri RF and Balipara RF, respectively). Grasses had the lowest potential biomass stock, with only 4.49 and $2.87 \%$ contribution for Bhomoraguri and Balipara $\mathrm{RF}$, respectively. Nevertheless, the overall amount of biomass recorded in the present study suggests promising $\mathrm{CO}_{2}$ removal by vegetation. Additionally, the study demonstrates the importance of prioritizing conservation efforts for plant species that contribute significantly to stocks, such as T. grandis, A. integer, D. sissoo, F. carica, M. elengi and $S$. chelonoides. They provide a significant opportunity for carbon sequestration and may result in carbon credits for the Reduced Emissions from Deforestation and Forest Degradation scheme.

Variation in biomass among tree species could be attributed to plant density and diversity changes, which are positively associated with tree stock. Changes in forest structure and tree species composition caused by anthropogenic disturbances threaten forest biomass stocks. Anthropogenic disturbances affect herbaceous species growth, development, and yield. Forest fire, overgrazing, and herb extraction for medicinal plants may have affected regeneration, resulting in lower herbaceous productivity and potential stocks (Subashree, Sundarapandian 2017; Nohro, Jayakumar 2020). Furthermore, the low biomass and carbon stock in the herbaceous layer may be due to shading by trees, which lowers light penetration and can also affect the physicochemical properties of the soil. Other factors such as tree age and size, climate, terrain, and disturbance regime (Dibaba et al. 2019) may have influenced both aboveground and belowground biomass.

On the other hand, the observed variation could be due to differences in the types and ages of trees that dominated the forests. Old-growth forests absorb more biomass and carbon and have high net primary productivity (Kothandaraman et al. 2020; Sheikh et al. 2020). The older trees have a larger diameter at breast height, and hence a major portion of carbon stock. Furthermore, a mature natural stand has larger diameter classes and accumulate more biomass, giving a larger carbon stock (Thokchom, Yadava 2017). Similar data were reported on the contribution of large tree diameter classes to biomass stocks (Raha et al. 2020).

Other factors that may have contributed to the inconsistencies include changes in forest management, the allometric model used, canopy cover, basal area, plant species density, and the height of existing species (Gandhi, Sundarapandian 2017; Dibaba et al. 2019; Pradhan et al. 2019; Kothandaraman et al. 2020). As a result, the necessity for conservation and sustainable use of plant resources in reserve forests is important because they store potential biomass and carbon. These reserve forests must be maintained from disturbances and degradation to improve their vegetation composition and biomass storage. The findings from the present study are consistent with previous studies in tropical and dry tropics of India (Dar, Sundarapandian 2015; Behera et al. 2017; Naveenkumar et al. 2017; Giri et al. 2019; Pradhan et al. 2019; Khan et al. 2020; Raha et al. 2020; Sheikh et al. 2020). However, the present results on biomass and carbon stocks are lower than those reported by Gandhi, Sundarapandian (2017), and Kothandaraman et al. (2020), as shown in Table 7. The discrepancies identified in the current study from other reported data may be attributed to changes in tree size, sample, location and forest characteristics, density, basal area, and forest maturation. 
Table 7. Reported data on plant biomass and carbon stocks from different Indian tropical forests for comparison

\begin{tabular}{|c|c|c|c|c|c|}
\hline \multirow[t]{2}{*}{ Forest } & \multirow{2}{*}{$\begin{array}{l}\text { Herb biomass } \\
\qquad\left(\mathrm{t} \mathrm{ha}^{-1}\right)\end{array}$} & \multicolumn{3}{|c|}{ Tree stocking potential $\left(\mathbf{t} \mathbf{h a}^{-1}\right)$} & \multirow[t]{2}{*}{ References } \\
\hline & & AGB & BGB & TB & \\
\hline Assam dry tropical forests & $8.05-69.36$ & $109.01-131.75$ & $28.34-34.25$ & $137.34-166.01$ & Present study \\
\hline $\begin{array}{l}\text { Manipur tropical forest, } \\
\text { Northeast India }\end{array}$ & $0.55-0.99$ & $18.27-21.93$ & - & - & Devi, Yadava 2015 \\
\hline $\begin{array}{l}\text { Kanyakumari WLS, Western } \\
\text { Ghats }\end{array}$ & $7.2-46.5$ & - & - & - & $\begin{array}{l}\text { Subashree, Sundarapandian } \\
2017\end{array}$ \\
\hline $\begin{array}{l}\text { Kashmir template forest } \\
\text { Himalaya }\end{array}$ & $0.16-3.10$ & - & - & $100.8-294.8$ & Dar, Sundarapandian 2015 \\
\hline $\begin{array}{l}\text { The tropical forest of the Javadi } \\
\text { Hills }\end{array}$ & $3.6-9.3$ & - & - & $99-216$ & Naveenkumar et al. 2017 \\
\hline $\begin{array}{l}\text { Nambor Wildlife Sanctuary, } \\
\text { Assam }\end{array}$ & $0.16 \pm 0.04$ & 192.99 & 50 & 242.99 & Giri et al. 2019 \\
\hline Katerniaghat WLS, Assam & - & $215.58-455.99$ & - & - & Behera et al. 2017 \\
\hline Chhattisgarh forest, India & $0.68-3.40$ & - & - & - & Khan et al. 2020 \\
\hline $\begin{array}{l}\text { Tropical forests of Western } \\
\text { Ghats }\end{array}$ & $0.17-19.07$ & - & - & $191.5-997.5$ & Kothandaraman et al. 2020 \\
\hline Central Himalaya & $8.1 \pm 1.29$ & - & - & 307.3 & Sheikh et al. 2020 \\
\hline $\begin{array}{l}\text { Protected forest of Western } \\
\text { Odisha }\end{array}$ & - & - & - & $281.6-310.95$ & Pradhan et al. 2019 \\
\hline Tropical deciduous Pradesh & - & - & - & $70.4-296.6$ & Raha et al. 2020 \\
\hline $\begin{array}{l}\text { Forest of Manipur, Northeast } \\
\text { India }\end{array}$ & - & $124.56-254.99$ & - & - & Thokchom, Yadava 2017 \\
\hline Sathanur, Eastern Ghats, India & - & $64.81-624.96$ & - & - & $\begin{array}{l}\text { Gandhi, Sundarapandian } \\
2017\end{array}$ \\
\hline
\end{tabular}

\section{Relationships between plant density, diversity and carbon stocks}

Although correlation does not always imply causation, the present investigation demonstrate potential and strong correlations between plant density, diversity and stocks. Tree and climber biodiversity attributes (diversity and density) strongly correlate with their potential carbon stocks. The finding suggests that an increase in the diversity and density of trees and climbers positively affects their biomass stocks. Grass density, on the other hand, despite being higher in both forests, exhibited a negative correlation with biomass, suggesting that increased grass species diversity does not promote carbon stocks. Moreover, the stocking capacity of grasses is determined by individual species rather than their density or diversity. Thus, understanding this relationship could result in the proper conservation of plant species with high stocking potential.

On top of that, relevant forest conservation and management initiatives for $\mathrm{CO}_{2}$ offset could be taken. Such initiatives could be advantageous and possibly relevant in the fight against severe climate change. Both linear regression equations and clustering observed in the present study explain the relationships among plant species in the studied forests. Tree and climber density and diversity favour higher carbon stocks than grass species. The poor potential stocks of grasses for Bhomoraguri and Balipara RF, indicates that grasses are inversely connected to their density and diversity. Similar findings were reported by
Gandhi and Sundarapandian (2017), and Raha et al. (2020) in Sathanur tropical dry deciduous forest, and Madhya Pradesh tropical dry deciduous forest, respectively. Furthermore, plant species greater diversity and density may have allowed a greater opportunity to include highly productive. Trees with variable tree canopy and seasonal phenology and nutrient uptake tend to complement each other (Kothandaraman et al. 2020), impacting potential stock (Behera et al. 2017). It was suggested that many tree associations promote more interactions and act as primary drivers determining carbon stocks (Raha et al. 2020).

\section{Conclusions}

The present study observed great dominance of species like Smilax ovalifolia, Piper betle, and Lantana camara in Bhomoraguri RF. These dominant and notorious plant species suppress the establishment and development of other understory species. They exhibited weed traits, which increased their density and frequency, and were able to resist extremely the effects of the tree canopy. They are aggressive colonizers, especially near forest borders and disturbed ecosystems. Moreover, grass species such as Aristida spp., Sida spp., and Cenchrus spp. are good indicators of disturbed ecosystems. The dominance of these species indicates the presence of numerous types of human-induced disturbances in the forests. Anthropogenic activities like encroachment, forest fires, overgrazing, 
extensive fuel-wood collection, and herb harvesting for medicinal could have significantly affected biodiversity.

The study demonstrated that biodiversity contributes significantly to forest ecosystem biomass and carbon stocks. Trees contributed the most to carbon stocks, while the herbaceous layer, mainly grasses, contributed less. Correlation analysis showed a significant relationship between biodiversity and carbon stocks, more positively linked with tree species and climber species. However, grasses showed a negative correlation with biomass and carbon stocks. The present findings imply that increased density and diversity of trees and climber species promote carbon stocks, while the density and diversity of grasses have a major negative effect on carbon stocks. The current study suggests that biodiversity attributes should be considered when addressing forest ecosystem potential stocks. Furthermore, the findings of this study demonstrate that the effectiveness of species-specific stocking differs as a result of a variety of circumstances. Thus, it is critical to carefully examine various biological and structural qualities to conserve and manage the reserve forests.

\section{Acknowledgements}

We gratefully acknowledge the financial support of the Indian Council of Cultural Relations (ICCR) for the first author. The approval of the Forest Department West Division of the Sonitpur district to conduct the study in their Reserve forests is greatly appreciated. We truly appreciate the Department of Environmental Sciences at Tezpur University for providing outstanding laboratory facilities.

\section{References}

Banik B., Deb D., Deb S., Datta B.K. 2018. Assessment of biomass and carbon stock in Sal (Shorea robusta Gaertn.) forests under two management regimes in Tripura, Northeast India. J. Forest Environ. Sci. 34: 209-223.

Baruah I., Das N.G., Kalita J. 2007. Seasonal prevalence of malaria vectors in Sonitpur district of Assam, India. J. Vector Borne Dis. 44: 149-153.

Baruah M.K., Chakraborty G., Choudhury M.D. 2013. Contribution to the flora of Barak Valley: conservation status and economic potential of herbaceous plant resources of Cachar District of Assam, India. Int. J. Bioresour. Stress Manage. 4: 137-146.

Begum S.S., Roy H., Nath M., Borthakur S.K. 2011. A sketch of the flora of Nameri National Park, Assam: II. Phytogeography. Pleione 5: 10-22.

Behera M.D., Tripathi P., Mishra B., Kumar S., Chitale V.S., Behera S.K. 2016. Aboveground biomass and carbon estimates of Shorea robusta and Tectona grandis forests using QuadPOL ALOS PALSAR data. Adv. Space Res. 57: 552-561.

Behera S.K., Sahu N., Mishra A.K., Bargali S.S., Behera M.D., Tuli R. 2017. Aboveground biomass and carbon stock assessment in Indian tropical deciduous forest and relationship withstand structural attributes. Ecol Eng. 99: 513-524.

Brand D.G., Leckie D.G., Cloney E.E. 1991. Forest regeneration surveys: design, data collection, and analysis. Forestry
Chronicle 67: 649-657.

Cedric C.D., Nfornkah B.N., Louis-Paul-Roger K.B., Claire N.J., Christian M.A., Bruno T.B.R., Forje G.W., Nadege M.T., Flore N.Y.A., Hubert M.K., Mirei T.V., Louis Z. 2021. Orchid diversity and biomass on a native host tree species in a semideciduous rain forest of Cameroon. J. Sustain. Forestry 40: 142-153.

Chambers J.C., Brown R.W. 1983. Methods for vegetation sampling and analysis on revegetated mined lands. Intermountain Forest and Range Experiment Station, Ogden. 57 p.

Chave J., Coomes D., Jansen S., Lewis S.L., Swenson N.G and Zanne A.E. 2009. Towards a worldwide wood economics spectrum. Ecol. Lett. 12: 351-366.

Chave J., Réjou-Méchain M., Búrquez A., Chidumayo E., Colgan MS., Delitti W.B.C., Duque A., Eid T., Fearnside P.M., Goodman R.C., Henry M., Martínez-Yrízar A., Mugasha W.A., Muller-Landau H.C., Mencuccini M., Nelson B.W., Ngomanda A., Nogueira EM., Ortiz-Malavassi E., Vieilledent G. 2014. Improved allometric models to estimate the aboveground biomass of tropical trees. Global Change Biol. 20: 3177-3190.

Chowdhury S. 2005. Assam's Flora: Present Status of Vascular Plants. Assam Science Technology and Environment Council, Guwahati.

Czapiewska N., Dyderski M.K. 2019. Seasonal dynamics of floodplain forest understory-impacts of degradation, light availability and temperature on biomass and species composition. Forests 10: 1-16.

Curtis J., McIntosh R. 1950. The interrelations of certain analytic and synthetic phytosociological characters. Ecology 31: 434455.

Dar J.A., Sundarapandian S. 2015. Variation of biomass and carbon pools with forest type in temperate forests of Kashmir Himalaya, India. Environ. Monit. Assessm. 187: 55.

Devi L.S, Yadava P.S. 2015. Carbon stock and rate of carbon sequestration in Dipterocarpus forests of Manipur, Northeast India. J. Forest Res. 26: 315-322.

Dibaba A., Soromessa T., Workineh B. 2019. Carbon stock of the various carbon pools in Gerba-Dima moist Afromontane forest, South-western Ethiopia. Carbon Balance Manage. 14: 1.

Dutta G., Devi A. 2013. Plant diversity and community structure in tropical moist deciduous sal (Shorea robusta Gaertn) forest of Assam, northeast India. J. Environ. Appl. Biores. 1: 1-4.

FSI. 1996. Volume equations for forests of India Nepal and Bhutan. Forest Survey of India, Ministry of Environment and Forests Government of India, Dehradun.

FSI. 2019. India State of Forest Report. Ministry of Environment, Forest \& Climate Change, Government of India. www.fsi.nic. in.

Gandhi D.S., Sundarapandian S. 2017. Large-scale carbon stock assessment of woody vegetation in the tropical dry deciduous forest of Sathanur reserve forest, Eastern Ghats, India. Environ. Monit. Assess. 187: 189-187.

Giri K., Buragohain P., Konwar S., Pradhan B., Mishra G., Meena D.K. 2019. Tree diversity and ecosystem carbon stock assessment in Nambor Wildlife Sanctuary, Assam. Proc. Natl. Acad. Sci. India Sect. B Biol. Sci. 89: 1421-1428.

Gogoi A., Sahoo U.K. 2018. Impact of anthropogenic disturbance on species diversity and vegetation structure of a lowland tropical rainforest of eastern Himalaya, India. J. Mount. Sci. 15: 2453-2465. 
Eggleston H.S., Buendia L., Miwa K., Ngara T., Tanabe K. 2006. IPCC Guidelines for National Greenhouse Gas Inventories. Institute of Global Environmental Strategies, Kanagawa.

Khan N., Jhariya M.K., Yadav D.K., Banerjee A. 2020. Herbaceous dynamics and $\mathrm{CO}_{2}$ mitigation in an urban setup: a case study from Chhattisgarh, India. Environ. Sci. Pollut. Res. 27: 28812897.

Konwar P., Saikia M.K., Saikia P.K. 2009. An abundance of food plant species and food habits of Rhinoceros unicornis Linn. in Pobitora Wildlife Sanctuary, Assam, India. J. Threat. Taxa 1: 457-460.

Kothandaraman S., Dar J.A., Sundarapandian S., Dayanandan S., Khan M.L. 2020. Ecosystem-level carbon storage and its links to diversity, structural and environmental drivers in tropical forests of Western Ghats, India. Sci. Rep. 10: 13444.

Kumar P., Mishra A.K., Chaudhari S.K., Sharma D.K., Rai A.K., Singh K., Rai P., Singh R. 2021. Carbon sequestration and soil carbon build-up under Eucalyptus plantation in semi-arid regions of northwest India. J. Sustain. Forestry 40: 319-331.

Mabberley D.J. 2008. Mabberley's Plant-Book: a Portable Dictionary of Plants. $3^{\text {rd }}$ Ed. Cambridge University Press, Cambridge.

Malunguja G.K., Devi A., Kilonzo M., Rubanza C.D.K. 2020. Climate change mitigation through carbon dioxide $\left(\mathrm{CO}_{2}\right)$ sequestration in community reserved forests of northwest Tanzania. Arch. Agric. Environ. Sci. 5: 231-240.

Malunguja G.K., Thakur B., Devi A. 2021. Heavy metal contamination in forest reserved soils crossed by roads, ecological risks, and their effects on tree biomass stocking potential. /preprint available at https://assets.researchsquare. com/files/rs-762158/v1/d1daa2c4-d863-485d-bf833474a3e2ba91.pdf?c=1631887139/

Misra K. 1989. Manual of Plant Ecology. $3^{\text {rd }}$ Ed. IBH Publishing, Oxford.

Nath A.J., Tiwari BK., Sileshi GW., Sahoo UK., Brahma B., Deb S., Devi NB., Das AK., Reang D., Chaturvedi SS., Tripathi OP., Das DJ., Gupta A. 2019. Allometric models for estimation of forest biomass in North East India. Forests 10: 103.

Nath M.J., Bora A.K., Yadav K., Talukdar P.K., Dhiman S., Baruah I., Singh L. 2013. Prioritizing areas for malaria control using geographical information system in Sonitpur district, Assam, India. Public Health 127: 572-578.

Naveenkumar J., Arunkumar K.S., Sundarapandian S.M. 2017. Biomass and carbon stocks of a tropical dry forest of the Javadi Hills, Eastern Ghats, India. Carbon Manage. 8: 351-361.

Nohro S., Jayakumar S. 2020. Tree species diversity and composition of the Pala Wetland Reserve Forest, Mizoram, Indo-Burma hotspot, India. Biocatal. Agric. Biotechnol. 23:
101474.

Paletto A., Agnelli AE., Meo I.M. 2021. Carbon stock in deadwood: the mountain birch (Betula pubescens subsp. czerepanovii) forests in the Khibiny Mountains (Russia). J. Sustain. Forestry 40: 385-400.

Pielou E.C. 1966. Species-diversity and pattern-diversity in the study of ecological succession. J. Theor. Biol. 10: 370-383.

Pradhan A., Ormsby A.A., Behera N. 2019. A comparative assessment of tree diversity, biomass, and biomass carbon stock between a protected area and a sacred forest of Western Odisha, India. Ecoscience 26: 195-204.

Raha D., Dar J.A., Pandey P.K., Lone P.A., Verma S., Khare P.K., Khan M.L. 2020. Variation in tree biomass and carbon stocks in three tropical dry deciduous forest types of Madhya Pradesh, India. Carbon Manage. 11: 109-120.

Rubanza C.D.K., Shem M.N., Ichinohe T., Fujihara T. 2006. Biomass production and nutritive potential of conserved forages in silvopastoral traditional fodder banks (Ngitiri) of Meatu district of Tanzania. Asian-Australasian J. Anim. Sci. 19: 978-983.

Saleem I., Mugloo J.A., Baba A.A, Buch K. 2019. Biomass estimation of herbaceous species of Benhama area, Kashmir. J. Pharmacogn. Phytochem. 8: 2926-2929.

Sarkar M., Devi A. 2014. Assessment of diversity, population structure, and regeneration status of tree species in Hollongapar Gibbon Wildlife Sanctuary, Assam, Northeast India. Tropical Plant Res. 1: 26-36.

Saxena R., Nagpa B.N., Singh V.P., Srivastava A., Dev V., Sharma M.C., Gupta H.P., Tomar A.S., Sharma S., Gupta S.K. 2014. Impact of deforestation on known malaria vectors in Sonitpur district of Assam, India. J. Vector Borne Dis. 51: 211-215.

Shannon C.E., and Weaver W. 1949. The Mathematical Theory of Communication. The University of Illinois Press, Urbana. 117 p.

Sheikh M.A., Kumar M., Todaria N.P., Pandey R. 2020. Biomass and soil carbon along altitudinal gradients in temperate Cedrus deodara forests in Central Himalaya, India: Implications for climate change mitigation. Ecol. Indic. 111: 106025.

Shukla U. 1996. The Grasses of North-Eastern India, Scientific Publishers, Jodhpur, p 404

Simpson E.H. 1949. Measurement of diversity. Nature 163: 688.

Subashree K., Sundarapandian S. 2017. Biomass and carbon stock assessment in two savannahs of Western. Taiwania 62: 272282.

Thokchom A., Yadava P.S. 2017. Biomass and carbon stock along an altitudinal gradient in the forest of Manipur, Northeast India. Tropical Ecol. 58: 389-396. 